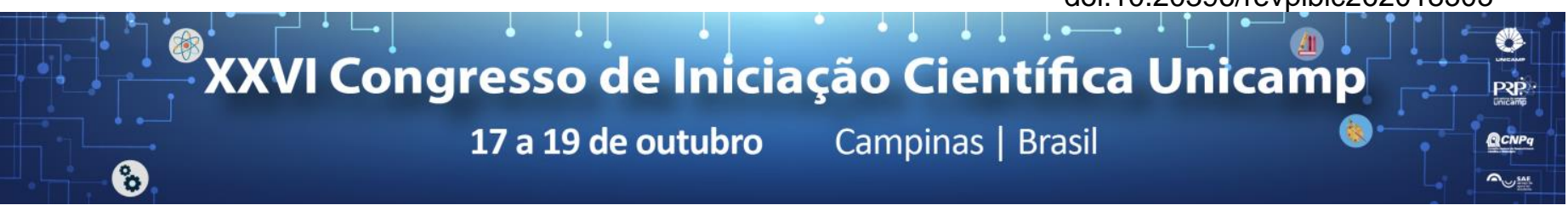

\title{
A atuação do BNDES no sistema financeiro nacional a partir de 2003: Mapeando um debate
}

\author{
André Martins Biancarelli, Catarina Campachi Carneiro da Silva*
}

\begin{abstract}
Resumo
A atuação de bancos públicos é motivo de discordância entre economistas de diferentes visões teóricas. No caso brasileiro, o banco de desenvolvimento, BNDES, é alvo de um intenso debate sobre às consequências de seu desempenho na economia nacional. Os críticos se baseiam na teoria convencional para expor a ideia da necessidade de diminuir o seu papel, enquanto os favoráveis fundamentam-se em uma visão desenvolvimentista para explicar a necessidade de órgãos estatais atuando na economia. Assim, esta pesquisa mapeou a discussão a respeito do Banco no período recente, mostrando as quatros principais ideias que compõem o debate.
\end{abstract}

\section{Palavras-chave:}

BNDES, banco público, debate.

\section{Introdução}

A partir de 2003, com as mudanças de diretrizes governamentais no Brasil e consequente ampliação das funções do BNDES no sistema financeiro nacional, principalmente após a crise financeira mundial, há um aparente crescimento do debate em relação a seu desempenho na economia brasileira. Entre os principais pontos de controversas estão os subsídios implícitos, os supostos custos fiscais gerados ao governo, a política de campeões nacionais e os possíveis empecilhos ao mercado de capitais. Visto o grande e influente papel exercido pelo banco no cenário nacional, esta pesquisa procurou mapear os principais argumentos sobre estas questões e compreender os reais impactos dessa instituição na economia brasileira de forma a assimilar os aspectos da crítica que se mostram verificável e contestar os que são puramente de cunho ideológico.

\section{Resultados e Discussão}

O BNDES é a principal instituição no Brasil de financiamento de longo prazo, sendo esse protagonismo de uma instituição pública alvo de intensas críticas.

Entre os pontos, está o subsídio implícito, discussão que gira em torno da TJPL, taxa de juros a qual o banco realiza seus empréstimos. O BNDES justifica o valor reduzido dessa taxa como forma de se opor a elevadíssima taxa de juros de curto prazo no país, decorrente de problemas estruturais advindos da acentuada inflação que marcou a economia brasileira nas últimas décadas do século passado. A visão convencional inverte este raciocínio. Argumenta que a TJPL permite a concessão de recursos subsidiados a um grande segmento do mercado de crédito, e assim proporciona uma série de distorções na economia, como a limitação da transmissão de políticas monetárias, impedindo a redução da Selic.

Outra questão, são os supostos custos fiscais, devido o diferencial entre os juros pagos pelo Tesouro Nacional, que disponibiliza recursos ao BNDES, e os praticados pelo banco. Para financiar a expansão da instituição, o governo ampliou significativamente a emissão de títulos da dívida pública. No entanto, argumenta-se que o Tesouro Nacional ao tomar empréstimo a uma taxa maior do que a cobrada pelos aportes concedidos ao banco cria um subsidio implícito que proporciona um aumento indevido sobre a dívida bruta do governo e uma forte pressão sobre o orçamento nacional. Em oposição a este discurso, autores desenvolvimentistas apontam que esta visão é limitada, uma vez que ao se concentrar no diferencial da taxa de juros não considera os impactos indiretos que esta medida tem sobre a economia. Argumentam que é preciso analisar os custos de equalização dos juros em empréstimos subsidiados e os benefícios gerados pela taxa de intermediação do BNDES com a transferência de lucros e dividendos para o Tesouro.

Outra discussão diz respeito a política de campões nacionais, no qual o Banco concedeu empréstimos a setores específicos da economia, como forma ajudar na recuperação da crise de 2008, aumentar o nível de investimento no país e identificar oportunidades de internacionalização em setores competitivos. A oposição aponta que essa política tem efeito limitado sobre o investimento e produtividade, cria problemas de seleção adversa, além de se concentrar em grandes empresas que não precisariam de recursos subsidiados.

Por fim, há também a discussão em relação ao mercado de capitais no país. Um lado argumenta que este é pouco desenvolvido devido ao BNDES, que com um custo de financiamento menor restringe a formação de novas formas. Os defensores do Banco, por outro lado, afirmam que a existência tímida dessa mercado decorre da seu alta volatilidade.

\section{Conclusões}

O debate em relação ao BNDES evidência, acima de tudo, um caráter político-ideológico das visões que se confrontam. Os críticos, atrelados ao pensamento econômico ortodoxo, apontam fundamentalmente a necessidade de repensar o papel desempenhado atualmente pelo banco. Por outro lado, os favoráveis à instituição, fundamentados em uma visão desenvolvimentista, argumentam ser essencial o seu papel para estimular o investimento no país, tanto público quanto privado, visto a alta taxa básica de juros vigente no Brasil. É importante destacar que a partir do governo Temer as ideias atreladas aos críticos do Banco ganharam força, sendo implantadas mudanças estruturais na instituição, alterando seu caráter. Entre esses casos estão a mudança da TJLP e a antecipação dos pagamentos ao Tesouro Nacional.

\section{Agradecimentos}

Agradeço ao professor Dr. André Biancarelli pela orientação e à instituição $\mathrm{CNPq} / \mathrm{PIBIC}$ pelo financiamento da pesquisa. 